\title{
Who Should Decide the Party's Nominee? Understanding Public Attitudes Toward Primary Elections
}

\author{
Zachary Albert \\ Department of Politics \\ Brandeis University \\ zalbert@,brandeis.edu \\ Raymond J. La Raja \\ Department of Political Science \\ University of Massachusetts, Amherst \\ laraja@umass.edu
}

\begin{abstract}
Primary elections in the US reflect the most inclusive nomination process among political parties across democracies. The desire for mass participation in party nominations appears embedded in a widespread populist ideal. It remains unclear, however, the extent to which voters believe that elites should be able to influence the process. Using data from the 2018 CCES we demonstrate that levels of political engagement, perceived ideological distance from the party, and partisanship predict the degree of support for popular selection of party nominees. We find key differences between the parties, with Republicans, particularly conservatives, more strongly opposed to elite influence. Surprisingly, most voters tend to have a pluralistic approach to selecting nominees, allowing for party officials and experts to weigh in on picking the party's candidates. The findings have implications for how we conceive of political parties and the kinds of nomination reforms that might be embraced by voters.
\end{abstract}




\section{Introduction}

Choosing candidates to run on the party label is a basic function of political parties.

Traditionally, the party leadership picks candidates, but in recent decades party organizations in many democracies have experimented with broadening the nomination selectorate to include party activists and dues-paying members of the party (Hazan and Rahat 2010). The United States is relatively unique in that its major parties have opened the process to voters in primary elections, including voters who may not affiliate with the political party. Nomination reforms in US presidential elections typically move in the direction of more open and inclusive processes (Gardbaum and Pildes 2018).

Surprisingly, despite democratizing rule changes over time there has been very little research to examine attitudes about the extent to which voters or political elites should determine who should carry the party label in the general election. In this analysis we evaluate public attitudes about who should influence the nomination. In doing so, we explore how preferences vary across voters depending on their perceptions of the parties and the degree to which they affiliate with them. Specifically, we explore how voters with a presumably strong stake in party nominations - including loyal partisans and ideologues - feel about different actors having influence in the selection process. Using data from the 2018 Cooperative Congressional Election Study, we ask voters a range of questions about primary elections. Most importantly we ask, how much influence should different actors have on a party's choice of nominees?

Our study about public attitudes toward the nomination is important in at least three respects, with practical and theoretical implications. First, on the practical side, arguments in favor of more or less public participation frequently arise in public debates about nomination reforms. This analysis provides an empirical foundation for understanding voter preferences, 
which could inform the design of nominations. Typically, the arguments in favor of or against reforms are made by different factions within political parties who feel disadvantaged by particular selection methods and invoke normative claims about democracy. To the degree that voters within and across the parties have different preferences regarding nomination processes, it is important to understand this variation and document which interests parties are responding to when they democratize (or not) their primary elections.

Second, this study gets at a larger theoretical debate regarding who constitutes and shapes the direction of the party through its nominations (Bawn et al. 2012; Cohen et al. 2008; Masket 2009). The power to choose nominees is arguably the defining act of party organizations. Rules matter for which actors get to participate in this choice (Key 1958; Polsby 1983; Schattschneider 1942) and for the expression of interests within the party (Duverger 1954; Kamarck 2016; Shafer and Wagner 2019; Rahat et al. 2008). By focusing on the preferences of voters regarding the nomination selection process we gain knowledge about who they see as appropriate influencers within a political party. More concretely in the US context, we are able to gauge different understandings of the two major parties by observing the attitudes of their partisans toward the selection process. Grossman and Hopkins (2016) argue that the parties are asymmetrically configured, with Republicans constituted as a party of conservatives and Democrats as a party of interests. If this is so, then we should be able to see distinctions between the parties in how they understand legitimate actors and what they view as key outcomes.

Third and finally, our motivation emerges more broadly from the tension between a populist ideal of democracy and research that highlights the importance of political parties serving as gatekeepers to thwart the selection of unfit or unrepresentative candidates (Achens and Bartels 2016; Levitsky and Ziblatt 2018; Rahat et al 2008). While scholars have been 
skeptics of internal party democracy (Katz 2001; Polsby 1983; Schattschneider 1942; Shafer 1988; Ware 2002), the practice appears to have widespread legitimacy in the United States and, increasingly, in other democracies (Gardbaum and Pildes 2018; Hazan and Rahat 2010). At the same time, we have little understanding of how much legitimacy voters assign to different actors who influence the process, including party voters, non-party voters, party officials and even nonpartisan experts. We hope this analysis contributes to an ongoing debate about how intraparty democracy affects different democratic values such as participation, competition, representation and vetting for quality leadership (Rahat et al. 2008; Spies and Kaiser 2012).

Our findings suggest that the most ideologically extreme and engaged voters, particularly conservatives who view the Republican party as too moderate, have strong preferences for populist methods of candidate selection. However, most voters appear to be pluralists, believing that other actors - including party leaders and political professionals - have a legitimate, though shared, role in influencing the nomination. We also observe a small group of citizens who might be considered elitists in believing that such decisions are best left to party professionals and experts. Our findings illustrate the power of ideology and political engagement in predicting preferences for preserving or enhancing populist methods of candidate nomination. In the conclusion we discuss the implications of these findings for party identities and reforms of the nominating process.

\section{Party Nominations}

The US party system uses a unique process to choose party nominees across a range of offices, opening the selection to mass voters who simply register with the party. In some states even nonaffiliated voters - independents - are permitted to vote in the primary election. In no other 
democracies do political parties allow for such an inclusive selectorate for nominations (Gardbaum and Pildes 2018; Hazan and Rahat 2010). At the federal level, these selection processes have become widespread for congressional elections since the early 20th century and for presidential elections since 1972 .

To this point, most research on US primary elections has fallen into two broad categories. One body of work focuses on electoral outcomes, including political competition and voting behavior in both congressional (e.g., Boatright 2013; Snyder and Ting 2011) and presidential primaries (e.g., Cohen et al. 2008; Mayer 2000; Norrander 2015). A second literature examines organizational outcomes, looking at how institutional rules alter candidate incentives and create downstream effects on party coalitions, media coverage, policies and representation (e.g., Ceaser 1982; McGhee et al. 2014; Norrander and Wedland 2017; Polsby 1983; Shafer 1988; Shafer and Wagner 2019). It seems surprising that, within this second stream of research, there has been little investigation about voter attitudes toward primary rules (but see Tolbert et al. 2009), particularly in light of democratizing reforms intended to shore up the legitimacy and grassroots enthusiasm for the political parties. ${ }^{1}$

\section{Populism and Alternative Traditions in the Nomination Process}

Our expectations about voter preferences regarding the nomination process are rooted in norms and traditions in the U.S. regarding democratic practices. We draw on these to conceptualize three sets of preferences in the nomination process. The most dominant norm has been described as the populist ideal of democracy (Dahl 2005). In its purest form this archetype celebrates the wisdom of popular judgment by informed and engaged citizens. Americans are socialized in the

\footnotetext{
${ }^{1}$ Herndon, Astead W, "Democrats Overhaul Controversial Superdelegate System," The New York Times, August $25^{\text {th }}$, 2018. https://www.nytimes.com/2018/08/25/us/politics/superdelegates-democrats-dnc.html?module=inline
} 
populist ideal through families, schools and popular culture, and they tend to understand popular sovereignty as the legitimate arbiter of government policy (Achens and Bartels 2016). The translation of popular sovereignty comes about through elections and various forms of direct democracy. Citizens who express strong preferences for broad participatory methods in selecting party nominees we call populists.

While populism is a dominant strain in the development of American political institutions, we also expect other traditions to affect public attitudes about democratic practices. One is the pluralist tradition that emphasizes the legitimate role of both formal and informal political institutions, including proxy representation by interest groups, political parties, nonprofits and other intermediaries (Dahl 2005; Truman 1951). The pluralist tradition highlights mixed systems of influence and balancing interests through decisions arrived at by bargaining and compromise among various actors (Cain 2014). In our study, pluralist voters are those willing to allow multiple actors - different sets of voters and elites - to influence the nomination process.

A third and final tradition that we explore is elitism, which in some ways is the antithesis of the populist norm. Voters in this group look to elites - preferably those with no self-interest to make decisions on behalf of the people. At first glance, deference to elites does not appear to be a strong part of American political culture, although some regions (the South especially) have been described as having more traditional political cultures with greater barriers to political participation (Elazar 1966). Research by Hibbing and Theiss-Morse (2002) reveals that a surprisingly large cohort of Americans do not want to participate regularly in politics and are, under some conditions, willing to allow decision-making outside the public's view, including by unelected officials. Some voters may also be elitists because they recognize that those in power 
are members of the same groups and would rather not give additional clout to voters who are not like them. In either case, we call such voters elitists because of their deference to elites in choosing the party's nominees. In sum, we explore the presence of three groups in the American electorate based on their attitudes toward primary elections: populists, pluralists and elitists.

\section{Explaining Preferences for Nomination Influencers}

Given the contemporary power of the populist ideal relative to other traditions, we expect most voters to hold strong participatory norms surrounding primary elections. That is to say, citizens will tend to prefer a definitive role for themselves, the voters, and minimal roles for other actors, including party leaders and non-partisan experts. Many Americans not only believe that they have the "political competence" to effectively participate (Almond and Verba 1963) but also that such participation is an important duty (Blais and Achen 2019). Thus, our expectation at the aggregate level is that citizens, by large margins, are biased towards a dominant role for voters in nomination contests.

Within this prevailing norm, however, we expect variation in preferences across a number of factors. First, because primaries are low-information affairs that tend to attract those most interested in politics (Gerber et al. 2017), we expect the populist ideal to be strongest amongst the most politically engaged (i.e. active, interested, and knowledgeable) primary voters. These voters feel efficacious and tend to value highly the civic act of voting, have strong preferences, and exhibit less deference toward political elites (Gerber et al. 2017). By contrast, voters who are less engaged are more likely to be pluralists or elitists. Such voters might think it practical to give some authority to others, especially if they feel they lack the information to make fully informed decisions, or have confidence in being virtually represented by 
professionals, or simply because they do not perceive the stakes of elections to be as high as engaged voters (Gerber et al. 2017).

We also expect the populist norm to be quite strong amongst passionate ideologues who perceive the party and its leaders as being distant from their own positions. These voters are most likely to distrust party leaders in choosing nominees because these elites are seen as “selling out" policy principles, e.g., Tea Party voters (see Williamson et al. 2011). When party leaders fashion internal compromises and build coalitions among factional interests in order to win elections these ideologues may see the party as moving further from their own positions. Perhaps more troublesome to policy-driven voters is when party elites compromise on policy issues with the opposition (Hibbing and Theiss-Morse 2002; Uslaner 1999). Such ideologues are also unlikely to put their faith in non-partisan experts or so-called 'independent' voters who might arrive at decisions which contradict their strongly-held preferences and pull party policies away from their ideal positions. The desire to select a party nominee who is closest to their relatively extreme positions means that such voters will want to minimize the influence in the selection process of compromising elites and nonpartisans. This effect might be especially strong for conservative ideologues who are generally more distrustful of elite experts (Grossmann and Hopkins 2016). Voters who perceive that the party aligns fairly well with their preferences, or who lack strong preferences, might be less concerned about decisions made by multiple actors (pluralists) or party representatives and experts (elitists).

Our expectations regarding partisan identity are slightly different. Because strong partisans are heavily invested in and supportive of their preferred party (Green et al. 2002), they might be more likely to defer to party leaders in primaries. That would mean stronger partisans, all else being equal, are more likely to be pluralists who understand the party as a broad coalition 
or elitists who are happy to leave decisions to the leaders and experts. To be sure, the relationship between strength of partisanship and support for the democratic norm might be mediated by ideology - if strong partisans are also ideologues, they could be supportive of a particular vision of what their party should be (and thus resistant to the moderating influences of party insiders and non-party voters).

More than strength of partisanship, however, we expect key differences between Republicans and Democrats in degrees of populism, particularly when conditioned on ideology. We expect Democrats to hold more pluralistic attitudes, thinking of themselves more as a party of interests (Grossmann and Hopkins 2016) and therefore more open to the influence of a broader set of actors in the party. At the same time, Republican adherents will be less likely to behave as pluralists, thinking instead of the party as the agent of a conservative ideological movement (Grossmann and Hopkins 2016) and making them less inclined to allow anyone but party voters to influence the nominations. The attraction of populist influence should be especially strong for Republicans who view the party as too moderate, since these voters are most likely to understand the party as a conservative movement.

In short, three factors - political engagement, perceived ideological distance from the party, and partisanship - should be predictably related to support for strong participatory norms in primaries. We acknowledge that voters often have weak preferences for questions about process, but within this context we expect a clear preference for the participatory norm, with variation in degree of adherence to populism, pluralism or elitism based on these three factors. Additionally, we also expect attitudinal differences among populists. These voters will tend to express preferences that define conventional understandings of populism. That is to say, they will express the most enthusiasm for participating in primaries and using them as a means of 
preventing political elites from interfering in the selection process. They are also most likely to see primaries as a method to pick a politician who reflects their beliefs and is unwilling to compromise principles.

\section{Data and Methods}

We utilize survey results from the 2018 Cooperative Congressional Election Study (CCES) to study attitudes towards primary elections. The CCES is a large, nationally representative survey administered in September and October (the "pre-election phase") and November (the "postelection phase") of 2018.

In the analyses that follow we analyze responses to common content questions as well as original survey questions designed for this project. ${ }^{2}$ The sample size is 2,000 respondents across two separate modules administered at roughly the same time. We especially focus on questions that ask respondents to allocate "influence points" to various actors who might impact primary elections and candidate selection. Respondents were told to allocate a total of 100 points to four separate actors: party voters, independent voters, party leaders, and nonparty experts. These actors are commonly discussed as plausible influencers in reform debates about the nominations. ${ }^{3}$ We use the point allocations to these political actors to identify ideal types in the electorate who represent populist, pluralist, and elitist attitudes towards the primary process.

To gain a greater understanding of how voters view the purpose of primaries, we also analyze responses to questions asking about the primary election process. Specifically, respondents are asked, on a five-point scale, how strongly they (dis)agree with the idea that

\footnotetext{
${ }^{2}$ The original survey questions can be found in the Supplemental Appendix.

${ }^{3}$ One obvious actor we do not include is the media. While political scientists have identified media influence in the nomination process (e.g., Bartels 1988), this insight is unlikely to be widespread among voters. Moreover, public discussions about nomination reform have not incorporated understandings about the news media as political actors.
} 
primary elections allow them to select candidates who reflect their beliefs, select the candidate most likely to win in the general election, prevent party leaders from picking candidates, and be involved in political decision-making. The first questions provide information about the degree to which populists, pluralists and elitist pick candidates based on their similar views or for strategic reasons, or both simultaneously. The last questions focus more on process, assessing whether respondents view primaries as a mechanism of accountability to thwart party elites and how much they value participation itself.

Finally, to assess the degree to which respondents believe politics is about standing true to principle or being accommodating, we asked them how much they agreed with the statement: "Politicians should not compromise if it means going against what the party stands for." Overall, the questions allow us to gauge respondents' perceptions of the primary process and to analyze motivations for participation and democratic practices. We expect populists to put a premium on participating in the process, thwarting elites and choosing candidates who share beliefs and do not compromise.

Our analysis proceeds in four stages. First, we provide descriptive statistics on point allocations and explain in greater detail the three categories of voters (populist, pluralist, and elitist) we identify. Second, we investigate the compositions of these categories, focusing on their partisan, ideological, and demographic makeup. Third, we more rigorously investigate the makeup of these categories using multinomial logistic regression models predicting membership in these categories. Finally, we explore in greater detail the attitudinal differences of the two dominant categories - pluralists and populists - and discuss the implications of these differences for reform efforts in the two parties. 


\section{Public Attitudes towards Primary Influencers}

As noted, we assess attitudes towards nominating processes by asking respondents to allocate 100 "influence points" to registered party voters, independent or unaffiliated voters, party leaders, and non-party experts. Figure 1 shows the distribution of points allocated to each of these actors, with the mean value for each category represented by a dashed line. Given the historically strong norm of mass participation, we expect most respondents to allocate the plurality of these points to voters, particularly voters who affiliate with the parties because partisans make up almost $2 / 3$ of the electorate. Indeed, the average respondent allocated significantly more points to party voters (mean of 42.4 points) than to independent voters (21.8 points), party leaders (18.9 points), and nonparty experts (16.9 points). ${ }^{4}$ Furthermore, a significant number of respondents gave influence points exclusively to party voters (allocating zero points to independents, party leaders, and nonparty experts). In other words, there is a notable preference for party voter influence and, for some respondents, a strong distaste for other actors.

Still, Figure 1 also shows significant variation in respondent point allocations. While the average number of influence points for party voters is relatively high, it is still less than a majority, suggesting that the average respondent prefers multiple actors to be engaged in the process. Furthermore, the distribution of points for registered party voters is

\footnotetext{
${ }^{4}$ In the Supplemental Appendix, we show the influence point distributions and means separately for respondents who identify with each of the two major parties. We do so as a preliminary step in identifying potential party differences in attitudes, though we find that the Republican and Democratic distributions appear quite similar.
} 

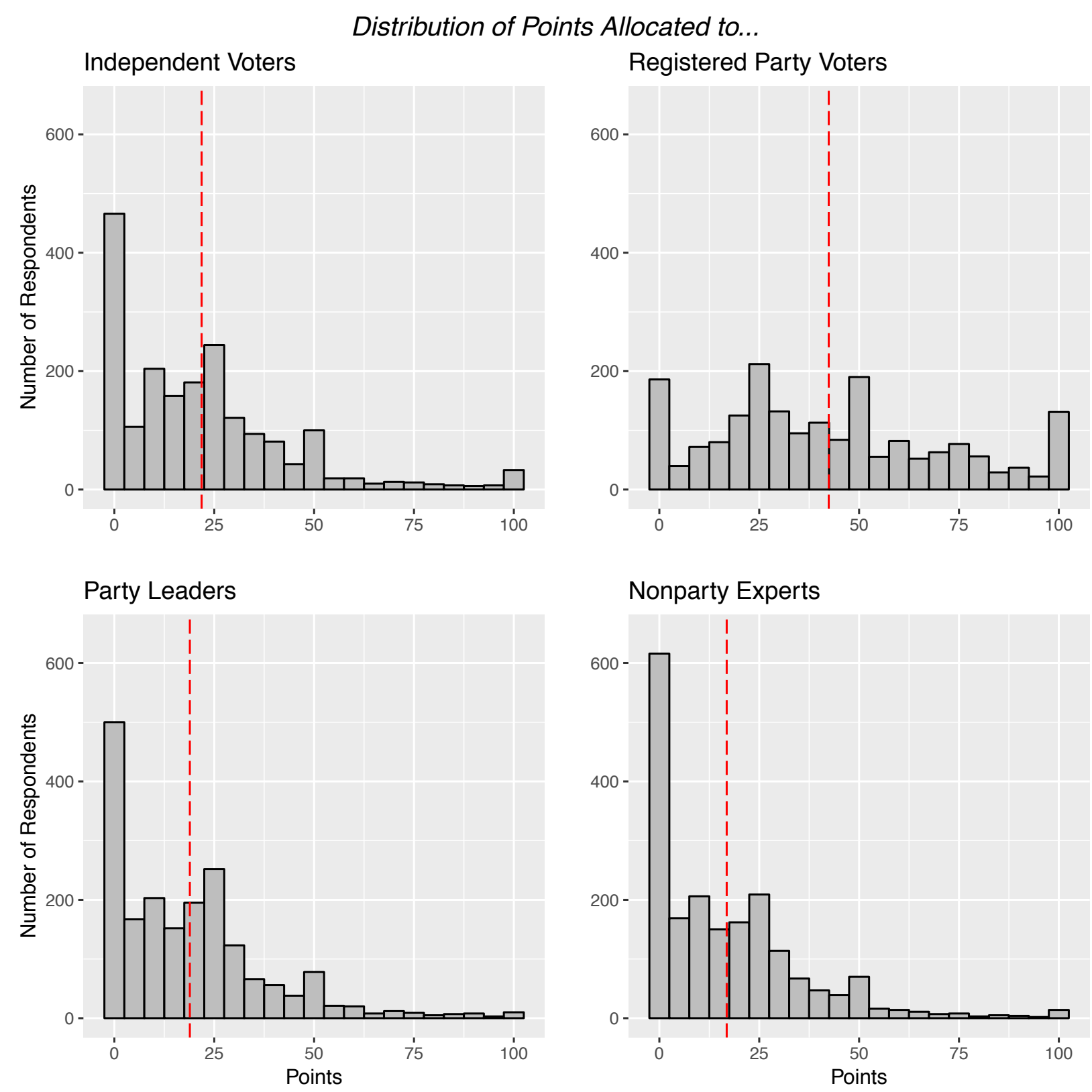

\section{Nonparty Experts}



Figure 1. Distribution of Influence Points

far less skewed than for any other actors, suggesting high variance in preferences for this category. A non-trivial number of respondents, for example, wanted only party voters to have influence, but an even larger proportion appears to have allocated equal influence to all four 
actor types. Still others appear to have given roughly half of the points to party voters and the other half to one or more other actors. Thus, while we have identified a populist impulse in our sample, we also observe what might be called pluralism, and even some elitism (we explain below how we measure these concepts).

\section{Populists, Pluralists, and Elitists}

Based on these distributions and the propositions we made about group differences, we cluster respondents into three categories that capture alternative beliefs about who should have influence in selecting party nominees. To delineate categories of democratic practices, we draw on Cain's (2014) conception of pluralism, in which no single actor has dominance in choosing outcomes. That is to say, we view point allocations in which no single actor receives a majority of points (i.e., non-dominance) as reflecting respondents who are pluralists. However, when point allocations generate a majority in favor of voters choosing nominees (i.e., the sum of points for party and independent voters is greater than 50), we conceive of these respondents as populists. When respondent point allocations generate a majority of points in favor of elites (i.e., the sum of party leaders and non-partisan experts) we call them elitists.

After weighting, populists comprise 40 percent of citizens while elitists represent just 11.3 percent of the American public (see Figure 2). The plurality of respondents (48.6 percent) are classified as pluralists, who acknowledge that multiple actors play a balanced and legitimate role in primary elections. Not surprisingly, these percentages change slightly in favor of the populist category when we examine only respondents who voted in the 2018 primary elections. In this case, a plurality of primary voters (46.1 percent) are classified as populists, with the six percentage point bump coming entirely from the pluralist category. Still, it is worth pointing out 
that a large percentage of even primary voters are pluralistic in their attitudes, allowing for various sources of influence on the nomination process.

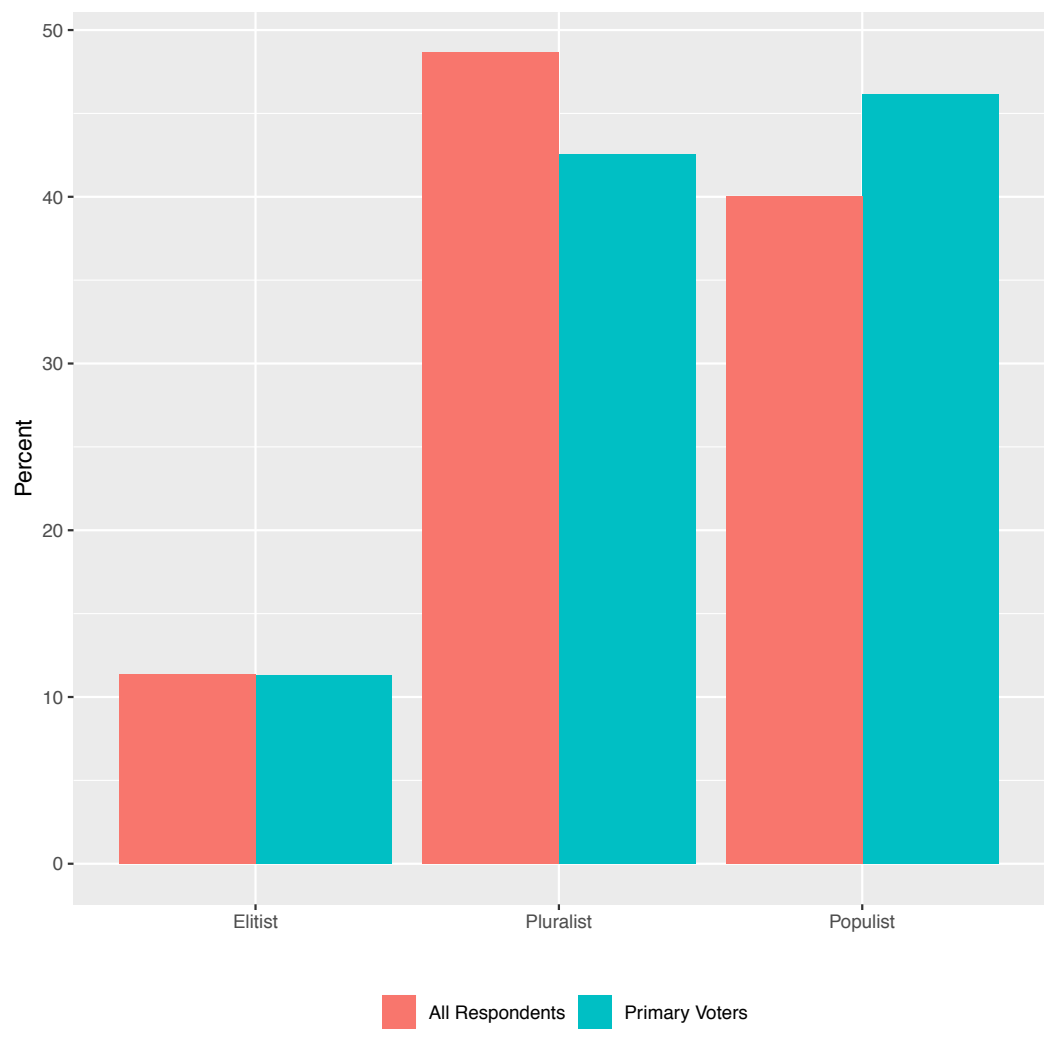

Figure 2. Category Sizes, All Respondents and Primary Voters

To begin to understand variation across these categories, Table 1 provides information on the political and demographic composition of respondents in each cluster. Cell values indicate the weighted percentage of respondents with particular characteristics (see row names) in each cluster (see column names). The final column represents the weighted percentage of all 


\begin{tabular}{|c|c|c|c|c|}
\hline & Populist & Pluralist & Elitist & $\begin{array}{c}\text { Total } \\
\text { Sample }\end{array}$ \\
\hline \multicolumn{5}{|l|}{ Partisan Strength } \\
\hline Strong Democrat & 26 & 23 & 26 & 24 \\
\hline Democrat & 9 & 16 & 15 & 13 \\
\hline Democratic Leaner & 9 & 10 & 11 & 10 \\
\hline Independent & 16 & 16 & 15 & 16 \\
\hline Republican Leaner & 11 & 9 & 9 & 10 \\
\hline Republican & 7 & 12 & 9 & 10 \\
\hline Strong Republican & 22 & 14 & 16 & 18 \\
\hline \multicolumn{5}{|l|}{ Ideology (self-declared) } \\
\hline Very Liberal & 13 & 15 & 16 & 14 \\
\hline Liberal & 19 & 19 & 20 & 19 \\
\hline Moderate & 28 & 34 & 32 & 31 \\
\hline Conservative & 24 & 22 & 19 & 23 \\
\hline Very Conservative & 17 & 10 & 14 & 14 \\
\hline \multicolumn{5}{|l|}{ Demographics } \\
\hline Female & 47 & 53 & 57 & 51 \\
\hline White & 78 & 66 & 71 & 71 \\
\hline Age (Mean) & 51 & 44 & 47 & 47 \\
\hline \multicolumn{5}{|l|}{ Participation, Interest, Knowledge } \\
\hline Primary Voter & 60 & 48 & 53 & 54 \\
\hline General Voter & 90 & 83 & 86 & 87 \\
\hline Campaign Donor & 24 & 17 & 22 & 21 \\
\hline Follow News (Most or Some of Time) & 82 & 69 & 75 & 75 \\
\hline Above Average Knowledge & 66 & 47 & 59 & 56 \\
\hline
\end{tabular}

respondents in the sample with particular characteristics. There are substantive and statistically significant differences across clusters for almost every variable investigated. Chi-square tests indicate that all differences, aside from the "campaign donor" variable, are statistically significant at $\mathrm{p}<0.05$. 
First, strong partisans are over-represented as populists. Both Strong Democrats and Strong Republicans make up nearly half of the populist category. In particular, Strong Republicans are over-represented (22 percent) as populists compared to their size in the full sample (18 percent) and under-represented as pluralists (14 percent) and elitists (16 percent). On the other hand, weaker partisans in both parties tend to be over-represented in the pluralist category. Overall, Democrats of all levels of party strength are over-represented in the elite category while Republicans are under-represented. We observe a somewhat similar pattern with respect to self-identified ideology. At the extremes, very conservative respondents are overrepresented among populists compared to the total sample, although very liberal respondents are not. Not surprisingly moderates are underrepresented among populists and overrepresented among pluralists and elitists.

We also observed differences in political engagement across the categories. As expected, populists tend to be highly involved, interested, and knowledgeable. Those who participate in politics in a number of ways - voting in primaries, voting in general elections, and donating to campaigns - are much more common in the populist category than in the pluralist or elitist categories. Even more striking, nearly 82 percent of populists follow the news some or most of the time compared to 69 percent for pluralists (and 75 percent for the entire sample). The proportion of populists with above average knowledge is 66 percent, well above voters in other categories. Overall, the levels of political interest and knowledge are significantly higher than the levels found amongst pluralists, elitists, and the full sample. Demographically, white and older respondents are overrepresented among populists, while female respondents are underrepresented. In contrast, the pluralist cluster contains a greater percentage of females, racial 
minorities, and younger voters than the overall sample. Finally, pluralists participate in and follow politics at the lowest rates among the three categories.

The voters in the elitist category are challenging to explain because, in theory, respondents could be elitists for different reasons. Given the small size of the elitist category and the fact that contemporary debates largely revolve around the concepts of pluralism and populism - we do not spend much time unpacking this group. Still, it is worth briefly outlining the two broad types of elitists that we identify. On the one hand, it is conceivable that some respondents are politically influential in other ways and do not necessarily favor broad-based voting that would dilute their influence. For example, nearly half of the respondents in this group took part in at least one political act beyond voting in 2018 (not shown), and elitists contribute to campaigns at higher rates than pluralists. Furthermore, elitist respondents have higher levels of political participation, interest, and knowledge when compared with pluralists (but lower levels when compared with populists), and the most knowledgeable elitists tend to take part in political acts at higher rates. Not all elitists, however, are knowledgeable and active. Indeed, the distribution of elitist political knowledge is fairly bimodal (not shown), suggesting that some may reflect voters who are relatively uninformed, disinterested, and inactive (Hibbing and Theiss-Morse 2002).

\section{Predicting Support for Primary Influencers}

Thus far we have investigated the political and demographic makeup of these three categories without accounting for the fact that several predictive variables are most likely interdependent. For this reason, we use two multinomial logistic regression models to predict respondents' 
categorization as populists, pluralists, and elitists. ${ }^{5}$ The first model assesses how well particular demographic and attitudinal factors predict primary attitudes, while the second model incorporates respondents' perceptions of the party actors whose influence they may or may not support in primary elections. In other words, in model two we are not simply interested in the respondent's self-declared ideology, but whether they believe the party is proximate or distant from them. We suspect that voters are particularly likely to be populists if they view the party as too moderate.

In these models we use the pluralist cluster as the baseline category in order to understand the factors that lead some respondents to hold more populist rather than pluralistic attitudes. Thus, the coefficients in the regression models represent the change in the log-odds of a respondent being in either the elitist or populist category rather than the pluralist category. Positive coefficients indicate that increasing values for a particular covariate are associated with greater log-odds of being in the elitist or populist categories, while negative coefficients suggest that increasing covariate values are associated with greater log-odds of being in the pluralist category.

Both models include explanatory variables related to our hypotheses regarding partisanship, ideology, and political activism. First, we include binary variables indicating the respondent's partisan affiliation. We group Democrats and Republicans of all types together to account for partisan asymmetries. ${ }^{6}$ We also include a PID Strength term to test whether stronger

\footnotetext{
${ }^{5}$ Some readers may disagree with our definition of who fits into these categories, suggesting, for example, that perhaps our category for populists is too broad. Sensitivity analysis, where we varied the measures of the concept, illustrates that our findings are even more powerful on the same factors when we define populists as those who favor supermajorities of voters influencing the decision rather than a bare majority. Furthermore, an analysis that strips away these conceptual categories and simply looks at what predicts preferences for specific types of influencers does not provide additional insights (see the Supplemental Appendix).

${ }^{6}$ The findings regarding partisan effects are similar in models that include binary variables for each level (e.g., strong Democrat, Democrat, and lean Democrat).
} 
partisans are more likely to hold populist attitudes. The term ranges from 0 to 3 , with higher values indicating stronger partisanship. To assess the effect of different ideologies, we include four binary variables for very liberal, liberal, conservative, and very conservative respondents. We focus here on respondents' self-identified ideology rather than latent, issue-based ideology scores in order to understand how respondents' political identities impact their attitudes towards primaries. $^{7}$

The second model also includes an additional ideology-based variable that accounts for the fact that respondents might hold more populist attitudes if they perceive their party as being ideologically 'distant' from themselves. For example, if an extreme ideologue who views their party as moderate might be more likely to distrust party leaders and more supportive of popular participation in primaries. For this reason, the Party Perception term in the second model measures the spatial distance between Democratic and Republican respondents' self-proclaimed ideology and their perception of their party's ideology. Both ideology measures are on the traditional 7-point scale ranging from very liberal to very conservative. The term is an ordered scale theoretically ranging from -6 to 6 , with positive values indicating that the respondent views their party as more moderate than themselves and negative values indicating that the respondent views the party as more ideologically extreme. The second model also includes two terms interacting this Party Perception measure with the Democratic and Republican terms to account for asymmetries across the two parties. Our expectation is that Republican voters who perceive the party as too moderate are most likely to be populists.

\footnotetext{
${ }^{7}$ We also ran models using latent ideological scores derived from 22 policy questions. The correlation between this latent ideology score and respondents' self-identified ideologies was 0.73 , and the effect of ideology on categorization was consistent across the models.
} 
Additionally, both models include a number of terms to measure the effect of political interest and participation on respondent classification. The Primary Voter term is a binary variable set to 1 if the respondent voted in the 2018 primary elections. The Activist Score is a scale ranging from 0 to 6 and measuring the number of political acts in which the participant engaged in 2018. ${ }^{8}$ The Political Interest term is an ordered scale from 1 to 4 , with higher values indicating that the respondent follows political news more frequently. Lastly, the Political Knowledge term measures respondents' understanding of current political affairs. This term is a scale from 0 to 6 indicating the number of political knowledge questions the respondent answered correctly. ${ }^{9}$

Finally, the models include controls for demographic factors typically related to political participation and attitudes. The Female and Racial Minority terms are binary variables set at 1 if the respondent is female or a racial minority and 0 otherwise. ${ }^{10}$ The Age variable simply represents the respondents' age. The Education term is a numeric variable ranging from 1 to 6 , with higher values indicating greater educational attainment.

The results from these regression models are presented in Table 2. When comparing elitist respondents to pluralists in the first model, the only statistically significant coefficient is the Political Knowledge term, suggesting that higher political knowledge increases the log-odds of a respondent being classified as an elitist. The fact that no other coefficients are statistically significant might reflect the small size or the heterogeneity of the elitist category.

\footnotetext{
${ }^{8}$ Political acts include attending a meeting, putting up a lawn sign, working for a campaign, attending a political event, contacting a public official, and donating to a campaign or organization.

${ }^{9}$ These questions asked respondents to identify the political party controlling the US House and Senate and the party identifications of their governor, representative, and two senators.

${ }^{10}$ Our results are unchanged when we replace the Racial Minority term with a binary variable for only black respondents.
} 
Table 2. Predicting Support for Primary Influencers

\begin{tabular}{|c|c|c|c|c|}
\hline & \multicolumn{2}{|c|}{ Model 1} & \multicolumn{2}{|c|}{ Model 2} \\
\hline & (a) & (b) & (a) & (b) \\
\hline & Elitist & Populist & Elitist & Populist \\
\hline \multirow[t]{2}{*}{ Democrat } & 0.292 & -0.644 & -0.334 & $-1.010 * * *$ \\
\hline & $(0.684)$ & $(0.442)$ & $(0.523)$ & $(0.373)$ \\
\hline \multirow[t]{2}{*}{ Republican } & -0.074 & -0.466 & -0.712 & $-0.601 *$ \\
\hline & $(0.717)$ & $(0.453)$ & $(0.522)$ & $(0.360)$ \\
\hline \multirow[t]{2}{*}{ PID Strength } & -0.045 & 0.068 & 0.269 & 0.300 \\
\hline & $(0.295)$ & $(0.189)$ & $(0.378)$ & $(0.253)$ \\
\hline \multirow[t]{2}{*}{ Very Liberal } & -0.202 & 0.370 & -0.303 & 0.196 \\
\hline & $(0.461)$ & $(0.302)$ & $(0.692)$ & $(0.479)$ \\
\hline \multirow[t]{2}{*}{ Liberal } & -0.034 & 0.187 & 0.195 & 0.342 \\
\hline & $(0.401)$ & $(0.270)$ & $(0.532)$ & $(0.401)$ \\
\hline \multirow[t]{2}{*}{ Conservative } & -0.039 & 0.132 & -0.253 & -0.114 \\
\hline & $(0.412)$ & $(0.257)$ & $(0.588)$ & $(0.401)$ \\
\hline \multirow[t]{2}{*}{ Very Conservative } & -0.14 & $0.736^{* *}$ & -1.183 & -0.058 \\
\hline & $(0.582)$ & $(0.332)$ & $(0.778)$ & $(0.487)$ \\
\hline \multirow[t]{2}{*}{ Party Perception } & & & 0.149 & $0.155^{* * *}$ \\
\hline & & & $(0.091)$ & $(0.059)$ \\
\hline \multirow[t]{2}{*}{ Primary Voter } & 0.269 & -0.172 & 0.064 & -0.080 \\
\hline & $(0.307)$ & $(0.191)$ & $(0.368)$ & $(0.248)$ \\
\hline \multirow[t]{2}{*}{ Activist Score } & 0.069 & 0.042 & 0.066 & 0.087 \\
\hline & $(0.105)$ & $(0.067)$ & $(0.132)$ & $(0.081)$ \\
\hline \multirow[t]{2}{*}{ Political Interest } & -0.137 & $0.197^{*}$ & -0.246 & 0.122 \\
\hline & $(0.170)$ & $(0.115)$ & $(0.221)$ & $(0.159)$ \\
\hline \multirow[t]{2}{*}{ Political Knowledge } & $0.229 * * *$ & $0.122 * *$ & $0.252 * *$ & $0.157^{* *}$ \\
\hline & $(0.088)$ & $(0.056)$ & $(0.113)$ & $(0.073)$ \\
\hline \multirow[t]{2}{*}{ Education } & -0.089 & 0.053 & -0.154 & 0.017 \\
\hline & $(0.096)$ & $(0.060)$ & $(0.118)$ & $(0.077)$ \\
\hline
\end{tabular}




\begin{tabular}{|c|c|c|c|c|}
\hline Female & $\begin{array}{c}0.112 \\
(0.278)\end{array}$ & $\begin{array}{c}-0.354 * * \\
(0.171)\end{array}$ & $\begin{array}{c}0.178 \\
(0.349)\end{array}$ & $\begin{array}{l}-0.404 * \\
(0.219)\end{array}$ \\
\hline Racial Minority & $\begin{array}{l}-0.043 \\
(0.332)\end{array}$ & $\begin{array}{l}-0.131 \\
(0.222)\end{array}$ & $\begin{array}{l}-0.253 \\
(0.431)\end{array}$ & $\begin{array}{c}-0.23 \\
(0.295)\end{array}$ \\
\hline Age & $\begin{array}{l}-0.005 \\
(0.009)\end{array}$ & $\begin{array}{c}0.018 * * * \\
(0.006)\end{array}$ & $\begin{array}{l}-0.002 \\
(0.011)\end{array}$ & $\begin{array}{l}0.014 * \\
(0.007)\end{array}$ \\
\hline Party Perception X Democrat & & & $\begin{array}{c}-0.372 * * * \\
(0.133)\end{array}$ & $\begin{array}{l}-0.107 \\
(0.090)\end{array}$ \\
\hline Party Perception X Republican & & & $\begin{array}{c}0.521 * * * \\
(0.156)\end{array}$ & $\begin{array}{c}0.262^{* * *} \\
(0.101)\end{array}$ \\
\hline Constant & $\begin{array}{c}-1.444^{*} \\
(0.753)\end{array}$ & $\begin{array}{c}-1.820 * * * \\
(0.507)\end{array}$ & $\begin{array}{l}-1.046 \\
(0.835)\end{array}$ & $\begin{array}{c}-1.612 * * * \\
(0.599)\end{array}$ \\
\hline Akaike Inf. Crit. & $1,361.20$ & $1,361.20$ & 890.69 & 890.69 \\
\hline
\end{tabular}

A larger number of coefficients are statistically significant when we compare pluralists to populists (rather than to elitists). Moreover, several factors appear robust across both models. First, increased political knowledge increases the log-odds that a respondent is classified as a populist, though not as much as in the elitist models. Second, it appears that being female lowers the odds of holding populist attitudes while older respondents have higher odds.

Model 1 seems to suggest that being a partisan does not matter when predicting attitudes, while being Very Conservative is strongly associated with being a populist. However, our view is that it is not simply one's self-declared ideology that motivates populist attitudes but the perception that the party may be too far from your preferred ideological position. When we account for this in the second model, the results confirm expectations regarding the interplay 
between partisanship and ideological perceptions. ${ }^{11}$ First, as expected, being a partisan makes one less likely to be a populist. The effect is larger for Democrats, which supports the thesis of Democrats thinking of themselves more as a pluralistic party.

At the same time, respondent ideology is not statistically related to populist attitudes, at conventional levels, once we account for perceptions of party ideology. Instead, what matters for predicting populist attitudes is whether or not respondents believe that their party is too moderate. All else equal, when voters perceive their party as more moderate than themselves, they are more likely to be populists. Importantly, this effect is most potent in the Republican Party, seen clearly in the large and statistically significant interaction term for Republican party perceptions (and the statistically insignificant interaction term for Democratic party perceptions). That is to say, Republicans who perceive the party as being too moderate are much more likely to be populist.

The size of this effect can be seen in Figure 3, which shows the predicted probability of holding particular attitudes, for members of each party, based on the perceived ideological distance between the respondent and their party. The x-axis represents the difference between the respondent's perception of their party's ideology and their own ideological self-placement, so that respondents on the left side view their party as more extreme than themselves, respondents in the middle share the same ideology as their party, and respondents on the right side view their party as less extreme than themselves. In both graphs, the sharply sloped lines for populist and pluralist predicted probabilities indicate that respondents become much more likely to hold populist attitudes - and much less likely to hold pluralistic ones - as they move from viewing their party as more extreme to less extreme than their own ideology. This effect is especially

\footnotetext{
${ }^{11}$ Based on the Akaike Information Criteria values for each model, the second model does a noticeably better job explaining attitudes toward primary influence.
} 
pronounced for Republican Party members. For example, a Republican respondent who perceives that the Republican Party shares their ideology has a 0.38 predicted probability of being a populist, but a similar Republican respondent who is strongly conservative and views the Republican Party as liberal has a 0.62 predicted probability of holding populist attitudes. A moderate Republican who views their party as ideologically extreme, on the other hand, has only a 0.19 predicted probability of holding populist attitudes (and a 0.78 predicted probability of having pluralistic attitudes).
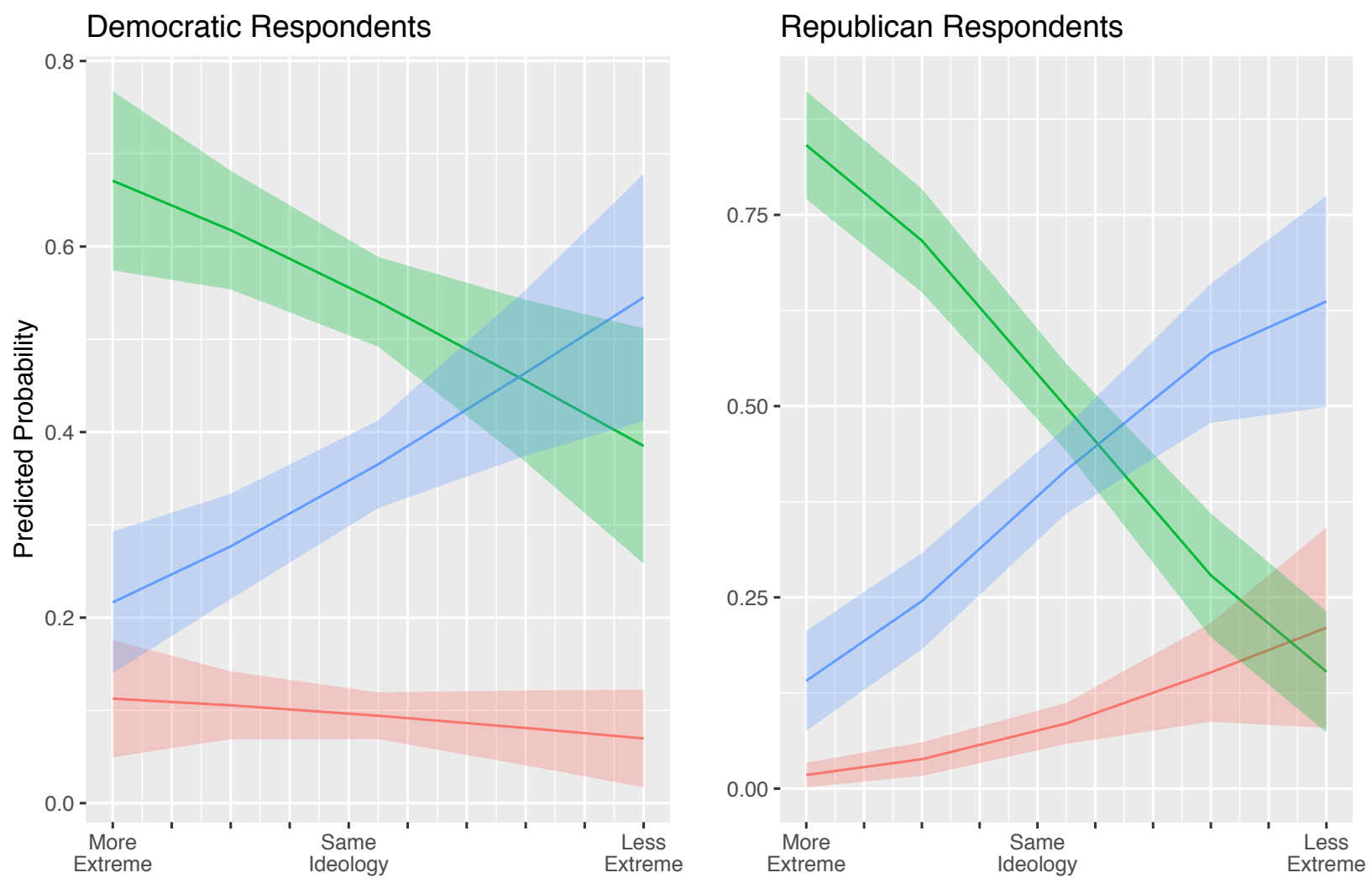

Perception of Party Ideology Relative to Respondent Self-Placement

— Elitist — Pluralist — Populist

Figure 3. Predicted Probability of Attitudes by Party ID and Ideological Perceptions 
Altogether, Republicans who are more moderate than their party tend to be pluralists, while those who are more conservative are quite likely to be populists. This finding supports the research of Grossmann and Hopkins (2016), who argue that the Republican Party tends to reflect the dynamics of conservative movements rather than a coalition of interests. In this way, conservative Republican voters who view party leaders as insufficiently ideological may be more disposed to prefer voters to be the agents of accountability to ensure ideological purity. The perceived ideology effect is not statistically significant for Democrats, though it is noteworthy that Democrats who perceive their party as too moderate are roughly equally as likely to be pluralists and populists, while the overall tendency for Democrats is to hold pluralistic attitudes.

\section{Populist Preferences for Political Outcomes}

Our analysis thus far has identified a notable divide between those who hold more pluralistic and more populist attitudes towards influence in primary elections. Since public debates in both parties tend to focus on calls for more open, populist nominating contests (Norrander 2015) it is worth exploring the kind of outcomes populists and other voters desire from primary elections in order to gain a better understanding of different expectations about the nomination process. Do populists use their participation in primaries to further distinct political goals?

To gain traction on this topic, we asked respondents whether they believe that primary elections serve various political goals. These questions allow us to understand not only who voters think should be influential but also to what ends they wield this influence. We expect that populists - given their perceived ideological distance from their party - are more likely to see primaries as mechanisms to hold the party accountable and to prevent the party from straying from their preferences. We also expect, given their strong adherence to the norm of popular 
participation, that they will be most likely to value their own participation in primaries, perhaps as an "expressive" good in its own right.

Figure 4 compares Democratic and Republican populists, pluralists, and rank-and-file members on each of these outcome questions, with bars representing the percentage within each party and cluster who agree or strongly agree with the statements. We limit the analysis to primary voters to focus attention on those most likely to impact primary outcomes. Interestingly, there are few differences when it comes to the type of nominee that respondents desire: a high percentage - across clusters and parties - use primary elections to select candidates who reflect their own beliefs. Furthermore, primary voters of all stripes, unsurprisingly, care about being involved in political decision-making.

Populist attitudes about primary outcomes are unique in some respects, though in different ways for Democrats than Republicans. Democratic populist voters are more likely than other Democrats and all types of Republicans to say that primaries allow them to prevent party leaders from deciding on the eventual nominee. Roughly 74 percent of Democratic populists say they use primaries to hold party leaders accountable, while only 65 percent of Democratic rankand-file and 60 percent of Democratic pluralists agree with this statement. This finding may reflect a strong anti-party sentiment which found a home in the Democratic Party as insurgent 'amateurs' challenged the power of 'professionals' running the urban party machines (Wilson 1962). The fullest expression of this anti-partyism emerged during the 1968 Democratic convention when activists challenged the premise that party leaders had the authority to select the presidential nominee without more inclusive participation (Kamarck 2016; Shafer 1983). This history may explain the Democratic Party's ongoing skirmishes over the party's nominating system for presidential elections, including the use of superdelegates. 


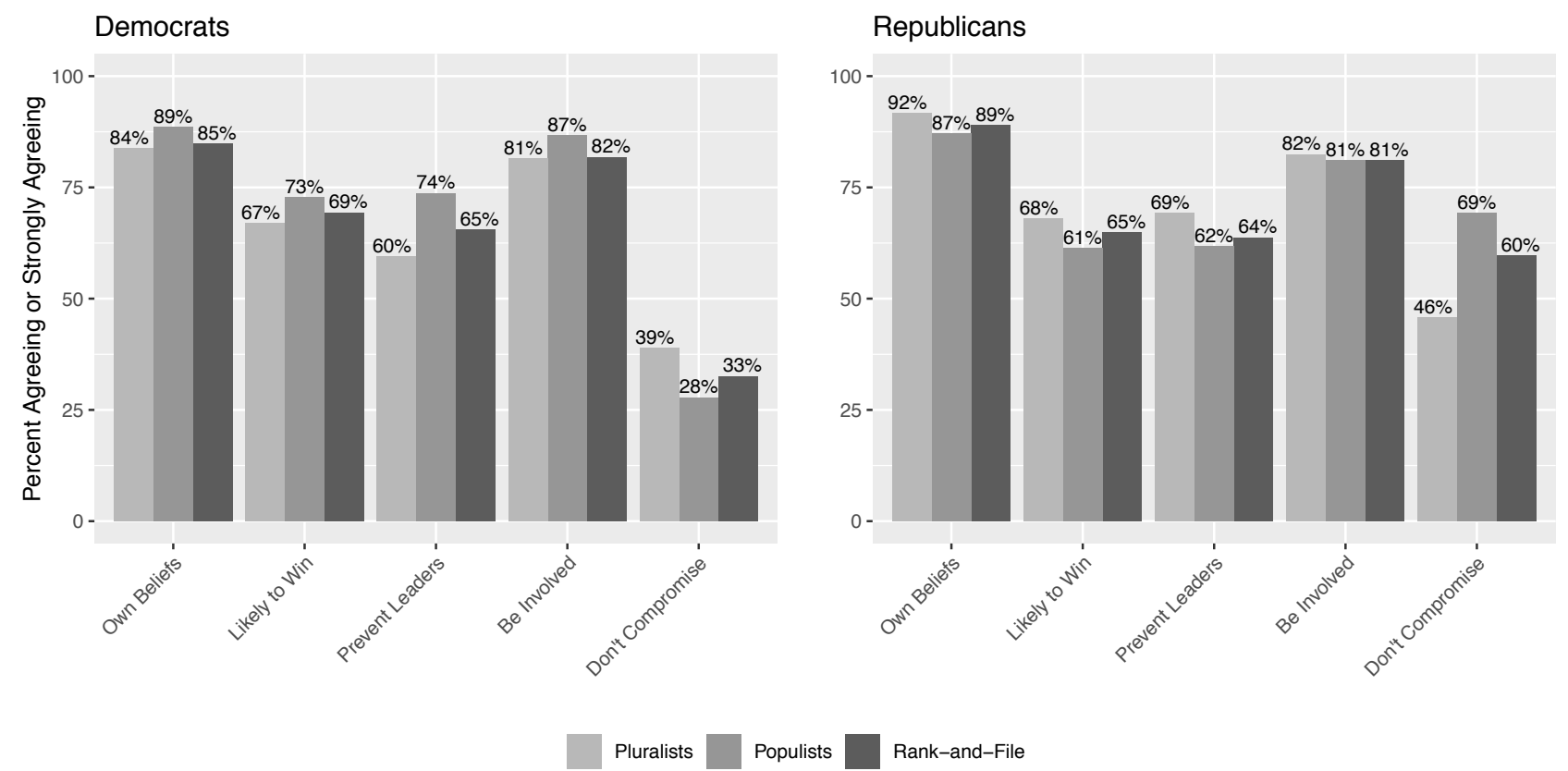

Figure 4. Political Outcomes by Cluster and Party

Republican populist voters, on the other hand, are far more likely to say that candidates should not compromise if it means going against the party's principles. Nearly 70 percent of Republican populist voters agree with this statement, while only 28 percent of Democratic populists feel the same (compared with 39 percent of Democratic pluralists and 33 percent of the Democratic rank-and-file). Even within the Republican Party, populist voters are far more opposed to compromise than Republican pluralists (46 percent) and Republican rank-and-file (60 percent).

Thus, while populists from both parties participate at relatively high rates and feel efficacious about this involvement, the two parties are in many ways appealing to distinct populist minorities when they institute democratizing reforms in primary elections. For Democrats, those in favor of more populism are actually less opposed to political compromise that dilutes their principles. This may reflect an understanding that the party as an organization has multiple interests. At the same time, Democratic populists are far more interested in 
preventing their party leaders from influencing primaries, which may reflect an historical and ongoing factional antipathy to hierarchy, particularly bossism. Republican populists, on the other hand, tend to be more ideologically extreme than their party and less open to compromise than their pluralist counterparts. Republicans also want to prevent party leaders from making the decision but not so much as the anti-party populists in the Democratic Party.

\section{Discussion}

The purpose of this study was to gain knowledge about public attitudes toward primary elections, which have become widespread since they were introduced more than a century ago. Taken together, our conceptual typology of democratic practices helps make sense of public attitudes towards nomination contests and contextualizes the prospects for reform. As expected, we found substantial evidence for a pervasive participatory norm among the American public. The average respondent prefers voters - especially registered party voters - to have the most influence in primary elections.

At the same time, however, most Americans appear to be pluralists, allowing for multiple actors to influence the selection of the party nominee. The largest group of respondents, who we measure at $49 \%$ of the electorate (and $43 \%$ of primary voters in 2018), supports a non-trivial role for party leaders and nonparty experts in candidate selection processes. These pluralists tend to be less interested and knowledgeable about politics, and Democrats are overrepresented among this group (though there are substantial numbers of Republicans and Independents as well). Importantly, these pluralists tend to participate in politics at lower rates compared with the two other analytic categories. 
Perhaps the most important category we analyze, given the participatory nature of American nominations, is the group of respondents who are disinclined to having elite influence in primary elections. These populists, who we measure at $40 \%$ of the electorate $(46 \%$ of primary voters), embrace the participatory norm strongly, preferring that voters - particularly partisans have the most influence in selecting nominees. Populists tend to be highly informed and interested in politics, and they participate at quite high rates. Additionally, populists appear to be ideologically extreme. More precisely, they are partisans who believe the party is too moderate. The larger the gap between their own preferences and their perceptions of the party's positions, the less they want party elites involved in decision-making. This dynamic is asymmetrically strong for Republicans, which suggests - in contrast to prior work (Freeman 1986) - that contemporary Republicans appear to be the more populist party, at least with respect to nomination decisions. Our finding that Republicans - and especially populists - are disinclined to want candidates to compromise on principles suggests that many voters in the Republican Party are highly concerned with maintaining ideological purity. Presumably, participation in primary elections is one way to do this.

Finally, we find a small percentage of respondents who prefer that party leaders and nonparty experts have the most power in primary elections. On average, elitists tend to be more politically knowledgeable than other voters, although they are heterogenous with many less knowledgeable voters in their ranks. We acknowledge that more data and research is needed to investigate this relatively small subgroup of voters.

We draw out several important implications from these findings. From a theoretical perspective the analysis lends insights about how the mass public understands an essential function of political parties and how they conceive of party institutions. For many Americans, 
the populist norm for choosing candidates is well ingrained, and they are not averse to giving voters who do not even affiliate with their party a choice in picking the candidate. At the same time, most voters acknowledge a role for party elites and other professionals in helping to choose candidates. Only 14 percent of respondents said voters exclusively should influence the nomination, and just 6 percent said it should be exclusively party voters. The willingness to allow different sets of actors to influence the process, be they political operatives or unaffiliated voters, suggests that voters tend to view parties as quite porous (Epstein 1986). The party primaries, in this sense, are viewed as arenas for individual political expression, particularly among ardent partisans, with some guidance from political elites. This is far from the model of “teams" of elites competing for office (Downs 1957; Sartori 1976; Schattschneider 1942) and closer to the model of parties as coalitions of interests with political elites influencing the nomination "invisibly" through endorsements and the allocation of other resources (Bawn et al. 2012; Cohen et al. 2008). The relative openness and porousness of American parties - and the public's desire for them to be this way - makes them vulnerable to party 'crashers' who may not be loyal to the party's historical commitments or competent to govern. Nonetheless, voters do not seem to be plebiscitary purists, indicating significant support for some professional vetting that would maintain a gatekeeping role for party organizations (Levitsky and Ziblatt 2018).

A second theoretical point emerges from the patterns we see across the parties. The divergent preferences of partisans for approaches to selecting the nominee appear to reflect the structural elements of each party. In this sense, we find support for an understanding of the two major parties as asymmetrical (Grossmann and Hopkins 2016). Republican partisans, who are inclined toward more populist methods of nominee selection, tend to be motivated more than Democrats by ideological concerns, while Democratic partisans, who are more likely to favor the 
pluralist approach, appear to support an understanding of a party that is constituted by interests and held together by necessary compromises.

The practical implications for reform are important. Both parties experience ongoing conflict over who should have influence in picking the party nominees for president (Cain and Gray 2018; Kamarck 2016; Gardbaum and Pildes 2018). Notwithstanding the urging by some activists in both parties that party elites and professionals should stay neutral in the nomination process, the majority of voters appear to believe that there is a legitimate role for party officials and experts. Roughly half of Americans appear to desire a pluralistic system of non-dominance. That is to say, these voters prefer a system in which no single influencer had the majority of influence on the nomination selection. ${ }^{12}$ The trend toward pure plebiscites reflects the preferences of a very small faction of partisan voters.

\footnotetext{
12 Even among respondents in our populist category, the average preference is to give 85 percent of influence to voters and 15 percent to party elites/experts.
} 


\section{Works Cited}

Achen, Christopher H. and Larry M. Bartels. 2016. Democracy for Realists: Why Elections Do Not Produce Responsive Government. Princeton: Princeton University Press.

Almond, Gabriel, and Sidney Verba. 1963. The Civic Culture: Political Attitudes and Democracy in Five Nations. Princeton: Princeton University Press.

Bartels, Larry M. 1988. Presidential Primaries and the Dynamics of Public Choice. Princeton: Princeton University Press.

Blais, André and Christopher H. Achen. 2019. "Civic Duty and Voter Turnout," Political Behavior, 41(2), 473-497.

Boatright, Robert G. 2013. Getting Primaried: The Changing Politics of Congressional Primary Challenges. Ann Arbor: University of Michigan Press.

Cain, Bruce E. 2014. Democracy More or Less: America's Political Reform Quandary. Cambridge: Cambridge University Press.

Cain, Bruce E. and Cody Gray. 2018. "Parties by Design: Pluralist Party Reform in a Polarized Era," New York University Law Review, 93: 636-632.

Ceaser, James W. 1982. Reforming the Reforms: A Critical Analysis of the Presidential Selection Process, 1982. Ballinger Publishing.

Cohen, Marty, David Karol, Hans Noel, and John Zaller. 2008. The Party Decides: Presidential Nominations Before and After Reform. Chicago: University of Chicago Press.

Dahl, Robert A. 2005. Who Governs? Democracy and Power in an American City, $2^{\text {nd }}$ Ed. New Haven: Yale University Press.

Downs, Anthony. 1957. An Economic Theory of Democracy. New York: Harper.

Elazar, Daniel J. 1966. American Federalism: A View from the States. New York: Crowell.

Epstein, Leon D. 1986. Political Parties in the American Mold. Madison: University of Wisconsin Press.

Freeman, Jo. 1986. "The Political Culture of the Democratic and Republican Parties," Political Science Quarterly, 101: 327-356.

Gardbaum, Stephen and Richard H. Pildes. 2018. "Populism and Institutional Design: Methods of Selecting Candidates for Chief Executive Symposium: A Debatable Role in the Process," New York University Law Review, 93:647-708.

Gerber, Alan S., Gregory A. Huber, Daniel R. Biggers, and David J. Hendry. 2017. "Why Don’t People Vote in U.S. Primary Elections? Assessing Theoretical Explanations for Reduced Participation," Electoral Studies, 45: 119-129.

Green, Donald P., Bradley Palmquist, and Eric Schickler. 2002. Partisan Hearts and Minds: Political Parties and the Social Identities of Voters. New Haven: Yale University Press.

Grossmann, Matthew, and David A. Hopkins. 2016. Asymmetric Politics: Ideological Republicans and Group Interest Democrats. New York: Oxford University Press.

Hazan, Reuven Y. and Gid'on Rahat. 2010. Democracy Within Parties: Candidate Selection Methods and their Political Consequences. New York: Oxford University Press.

Hibbing, John R. and Elizabeth Theiss-Morse. 2002. Stealth Democracy : Americans' Beliefs About How Government Should Work. New York: Cambridge University Press.

Kamarck, Elaine Ciulla. 2016. Primary Politics: Everything You Need to Know About How America Nominates Its Presidential Candidates, $3^{r d}$ Ed. Washington, D.C.: Brookings Institution Press.

Katz, Richard. S. 2001. "The Problem of Candidate Selection and Models of Party Democracy," Party Politics, 7(3): 277-296. 
Levitsky, Steven and Daniel Ziblatt. 2018. How Democracies Die. New York: Crown.

Masket, Seth E. 2009. No Middle Ground: How Informal Party Organizations Control Nominations and Polarize Legislatures. Ann Arbor: University of Michigan Press.

Mayer, William G. 2000. In Pursuit of the White House 2000: How We Choose Our Presidential Nominees. New York: Chatham House Publishers.

McGhee, Eric, Seth Masket, Boris Shor, Steven Rogers, and Nolan McCarty. 2014. "A Primary Cause of Partisanship? Nomination Systems and Legislator Ideology," American Journal of Political Science, 58(2), 337-351.

Norrander, Barbara, and Jay Wendland. 2017. "Representativeness of Presidential Primary Voters in an Era of Polarized Parties," State of the Parties: 2016 and Beyond Conference, University of Akron, November 9-10, 2017.

Norrander, Barbara. 2015. The Imperfect Primary: Oddities, Biases and Strengths in U.S. Presidential Nomination Politics, $2^{\text {nd }}$ Ed. New York: Routledge.

Polsby, Nelson W. 1983. Consequences of Party Reform. Oxford: Oxford University Press.

Rahat, Gideon, Reuven Y. Hazan and Richard S. Katz. 2008. "Democracy and Political Parties: On the Uneasy Relationships between Participation, Competition and Representation," Party Politics, 14(6): 663-683.

Sartori, Giovanni. 1976. Parties and Party Systems: A Frameworkfor Analysis. New York: Cambridge University Press.

Schattschneider, E. E. 1942. Party Government. New York: Farrar and Rinehart.

Shafer, Byron E. 1983. Quiet Revolution: The Struggle for the Democratic Party and the Shaping of Post-Reform Politics. New York: Russell Sage Foundation.

Shafer, Byron E. and Regina L. Wagner. 2019. The Long War Over Party Structure. Cambridge: Cambridge University Press.

Snyder James M, and Michael M. Ting. 2011. "Electoral Selection With Parties and Primaries," American Journal of Political Science, 55: 781-795.

Spies, Dennis C. and André Kaiser. 2014. "Does the Mode of Candidate Selection Affect the Representativeness of Parties?” Party Politics 20(4): 576-590.

Truman, David Bicknell. 1951. The Governmental Process: Political Interests and Public Opinion. New York: Knopf.

Tolbert, Caroline J., David P. Redlawsk, and Daniel C. Bowen. 2009. "Reforming Presidential Nominations: Rotating State Primaries or a National Primary?" PS: Political Science \& Politics 42(1): 71-79.

Uslaner, Eric M. 1999. The Movers and the Shirkers: Representatives and Ideologues in the Senate. Ann Arbor: University of Michigan Press.

Williamson, Vanessa, Theda Skocpol, and John Coggin. 2011. "The Tea Party and the Remaking of Republican Conservatism," Perspectives on Politics, 9(1): 25-43.

Wilson, James Q. 1962. The Amateur Democrat: Club Politics in Three Cities. Chicago: University of Chicago Press. 


\section{Supplemental Appendix for "Who Should Decide the Party's Nominee? Understanding Public Attitudes Toward Primary Elections"}

\section{Survey Items}

The following questions were fielded on two separate CCES modules, administered at roughly the same time, in the pre-election (September and October 2018) questionnaire.

1. Primary Actor Influence ALLOCATE POINTS

Please randomize the order of the items list. Respondents should allocate a total of 100 points across the four categories, by moving each category label along a 100 point sideways scale. They should be able to allocate the same number of points to multiple categories, and they should be forced to allocate all 100 points.

In the United States, candidates must be nominated by a party before they can compete in a general election. There are many ways to nominate a party candidate. The most common is a primary election.

Please indicate your preference for how much influence each of the following actors should have on a party's choice of nominees by assigning 100 total "influence" points across each category (higher point values indicate that an actor should have more influence):

Items:

1 Independent voters and others who are not enrolled with a major party

$2 \quad$ Voters who register with that particular party

$3 \quad$ Party leaders

$4 \quad$ Non-partisan experts on political leadership

2. Primary Election Values

GRID

Please randomize the order of the item list (i.e. the rows) but do not change the scale (i.e. the columns).

Primary elections provide people like me an opportunity to...

Rows:

$1 \quad$... select a candidate who reflects my own beliefs.

2 ... select the candidate mostly likely to win in the general election.

$3 \quad$... prevent party leaders from picking candidates.

$4 \quad \ldots$ be more involved in political decision-making. 
Columns:

1 Strongly agree

2 Somewhat agree

3 Neither agree nor disagree

$4 \quad$ Somewhat disagree

5 Strongly disagree

3. Stealth and Strong Democracy

GRID

Please randomize the order of the item list (i.e. the rows) but do not change the scale (i.e. the columns).

Please indicate your level of agreement with the following statements:

Rows:

1 In general, I don't care that deeply about most policy debates that take place in national politics.

2 Politicians should not compromise if it means going against what the party stands for.

3 Americans largely agree how to fix the nation's problems but the political parties create unnecessary divisions.

Columns:

1

2

Somewhat agree

Neither agree nor disagree

$4 \quad$ Somewhat disagree

$5 \quad$ Strongly disagree

\section{Party Differences in Influence Point Allocations}

As a first step in understanding potential partisan differences in influence point allocations, Figure A1 depicts the distribution and mean points allocated to each primary actor type, grouped by respondents' partisan affiliations. The distributions are quite similar for members of both parties in terms of shape and inflection points. The means are also quite similar for both Democratic and Republican respondents for each actor type. The main difference across the parties is that Republicans are relatively more likely to hold exclusionary attitudes (i.e. allocate all or zero influence points) compared with Democrats. Specifically, Republican respondents allocate, at higher rates, either 100 or 0 influence points to party voters and 0 influence points to 
independent voters, party leaders, and nonparty experts. In the aggregate, though, members of both parties are fairly similar in their patterns of influence point allocation.
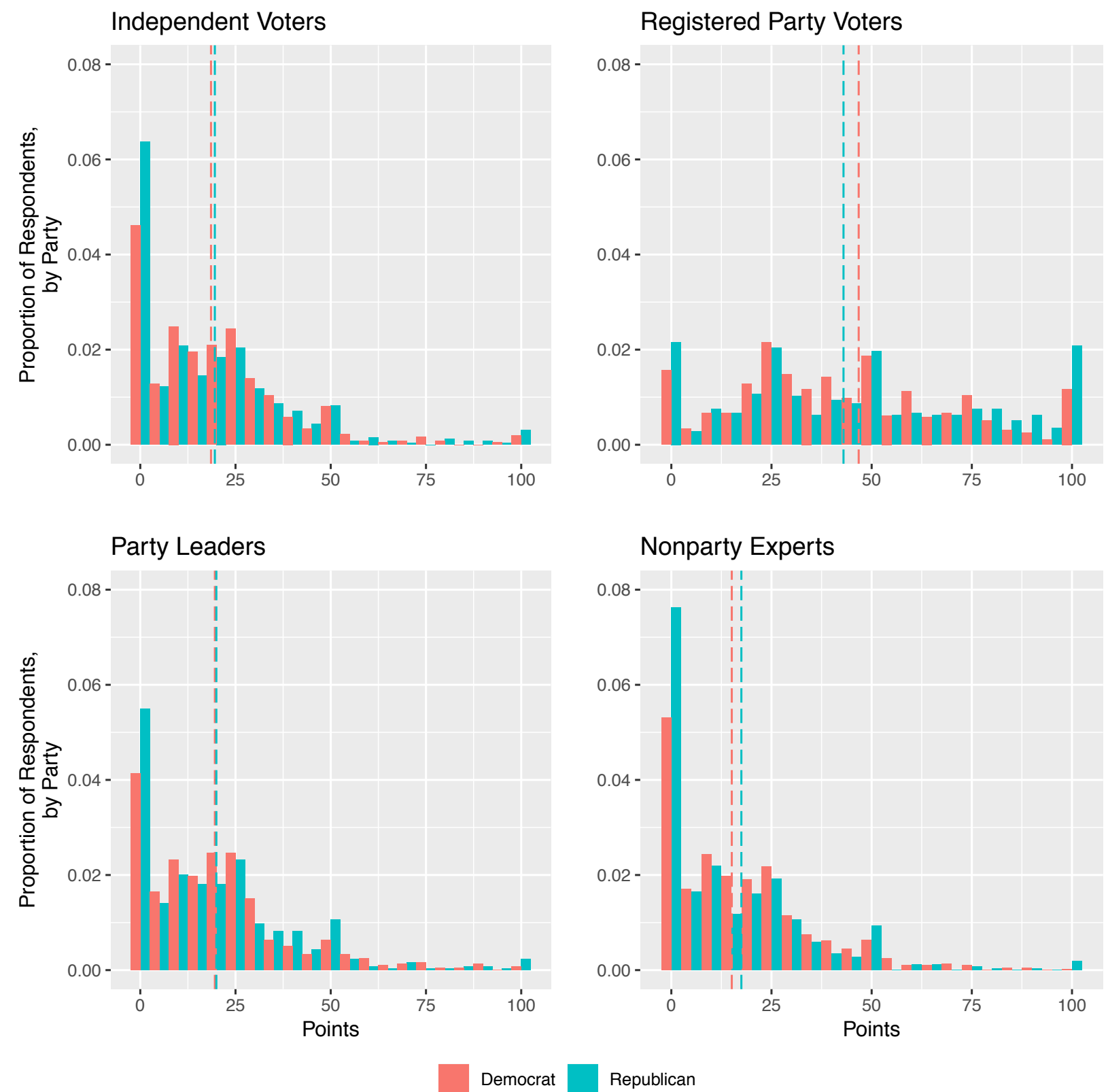

Figure A1. Point Allocations by Respondent Party Identification

\section{Validation of Cluster-Based Regression Models}

Some readers may object to our cluster-based analysis of primary attitudes, where we group respondents into one of three categories - populist, pluralist, and elitist - based on their 
allocation of influence points. To demonstrate that the results presented in this paper are not sensitive to this decision, we also run a model predicting point allocations (rather than cluster membership) using the same variables as those found in the main text. Specifically, we reproduce one model from the analysis using Seemingly Unrelated Regression (SUR), a model class that allows for the simultaneous estimation of several regression equations with related error terms or in which the dependent variables are structurally related. In our case, the allocation of points - capped at 100 - to one actor type is by definition related to the number of points allocated to the remaining actors. A SUR model allows us to assess the impact of various predictors on point allocations across actor types while also accounting for the fact that these allocations are part of a larger whole in which 100 total points were allocated.

In the four formulas in the SUR model below, the outcome variables are the number of points (from 0 to 100) a respondent allocated to each primary actor (party voters, independent voters, party leaders, and nonparty experts). We are only able to run the SUR model on the first model specification, i.e. the model without the Party Perception variable (and related interaction terms), due to insufficient observations when predicting influence point allocations across four separate categories. Thus, the model below includes only those coefficients included in Model 1 in the main text. Still, the results from the SUR model are largely consistent with the findings in Model 1. Table A1, which includes the results from this SUR model, shows that strong conservativism, high levels of political interest and knowledge, and older age are associated with increased support for party voters (i.e. populism). Relatedly, strong liberalism and conservativism and high levels of political knowledge are associated with decreased support for party leaders.

The fact that our Model 1 results are largely consistent with the results of the SUR model suggests that our findings are not sensitive to our clustering decision.

Table A1. Seemingly Unrelated Regression Analysis

\begin{tabular}{|c|c|c|c|c|}
\hline & Depen & t variable: & & \\
\hline & (a) & (b) & (c) & (d) \\
\hline & Party & Independent & Party & Nonparty \\
\hline & Voters & Voters & Leaders & Experts \\
\hline Democrat & $-9.301 *$ & 1.056 & 6.063 & 2.182 \\
\hline & $(5.466)$ & $(4.028)$ & $(3.809)$ & (3.349) \\
\hline Republican & -6.599 & 0.264 & 4.25 & 2.084 \\
\hline & $(5.588)$ & (4.117) & $(3.894)$ & $(3.424)$ \\
\hline PID Strength & 2.928 & $-3.09 *$ & 0.196 & -0.029 \\
\hline & $(2.350)$ & (1.732) & $(1.638)$ & $(1.440)$ \\
\hline Very Liberal & 5.305 & -1.932 & $-5.934 * *$ & 2.562 \\
\hline & $(3.748)$ & $(2.761)$ & $(2.611)$ & $(2.300)$ \\
\hline
\end{tabular}




\begin{tabular}{|c|c|c|c|c|}
\hline Liberal & $\begin{array}{c}2.89 \\
(3.330)\end{array}$ & $\begin{array}{l}-0.538 \\
(2.453)\end{array}$ & $\begin{array}{l}-1.841 \\
(2.320)\end{array}$ & $\begin{array}{l}-0.512 \\
(2.040)\end{array}$ \\
\hline Conservative & $\begin{array}{l}-0.430 \\
(3.192)\end{array}$ & $\begin{array}{c}0.162 \\
(2.352)\end{array}$ & $\begin{array}{c}-1.683 \\
(2.224)\end{array}$ & $\begin{array}{c}1.952 \\
(1.955)\end{array}$ \\
\hline Very Conservative & $\begin{array}{c}12.677 * * * \\
(4.031)\end{array}$ & $\begin{array}{l}-4.253 \\
(2.970)\end{array}$ & $\begin{array}{l}-5.238 * \\
(2.808)\end{array}$ & $\begin{array}{l}-3.187 \\
(2.470)\end{array}$ \\
\hline Primary Voter & $\begin{array}{c}-0.18 \\
(2.365)\end{array}$ & $\begin{array}{l}-2.355 \\
(1.743)\end{array}$ & $\begin{array}{c}1.749 \\
(1.648)\end{array}$ & $\begin{array}{c}0.786 \\
(1.450)\end{array}$ \\
\hline Activist Score & $\begin{array}{l}-0.207 \\
(0.822)\end{array}$ & $\begin{array}{c}-0.61 \\
(0.606)\end{array}$ & $\begin{array}{c}1.166 * * \\
(0.573)\end{array}$ & $\begin{array}{l}-0.349 \\
(0.504)\end{array}$ \\
\hline Political Interest & $\begin{array}{c}3.857 * * * \\
(1.418)\end{array}$ & $\begin{array}{c}-0.073 \\
(1.045)\end{array}$ & $\begin{array}{c}-2.633 * * * \\
(0.988)\end{array}$ & $\begin{array}{l}-1.152 \\
(0.869)\end{array}$ \\
\hline Political Knowledge & $\begin{array}{l}1.242 * \\
(0.695)\end{array}$ & $\begin{array}{c}-0.644 \\
(0.512)\end{array}$ & $\begin{array}{c}0.373 \\
(0.484)\end{array}$ & $\begin{array}{c}-0.972 * * \\
(0.426)\end{array}$ \\
\hline Education & $\begin{array}{c}1.565 * * \\
(0.741)\end{array}$ & $\begin{array}{c}-0.625 \\
(0.546)\end{array}$ & $\begin{array}{l}-0.738 \\
(0.516)\end{array}$ & $\begin{array}{c}-0.201 \\
(0.454)\end{array}$ \\
\hline Female & $\begin{array}{c}-4.703^{* *} \\
(2.145)\end{array}$ & $\begin{array}{c}0.067 \\
(1.580)\end{array}$ & $\begin{array}{c}0.958 \\
(1.494)\end{array}$ & $\begin{array}{c}3.678 * * * \\
(1.314)\end{array}$ \\
\hline Racial Minority & $\begin{array}{c}-4.862 * \\
(2.728)\end{array}$ & $\begin{array}{c}2.74 \\
(2.010)\end{array}$ & $\begin{array}{c}0.519 \\
(1.901)\end{array}$ & $\begin{array}{c}1.603 \\
(1.672)\end{array}$ \\
\hline Age & $\begin{array}{c}0.178 * * \\
(0.071)\end{array}$ & $\begin{array}{c}-0.009 \\
(0.053)\end{array}$ & $\begin{array}{c}-0.046 \\
(0.050)\end{array}$ & $\begin{array}{c}-0.123 * * * \\
(0.044)\end{array}$ \\
\hline Intercept & $\begin{array}{c}14.781 * * \\
(6.140)\end{array}$ & $\begin{array}{c}34.303 * * * \\
(4.524)\end{array}$ & $\begin{array}{c}26.288 * * \\
* \\
(4.278)\end{array}$ & $\begin{array}{c}24.628 * * * \\
(3.762)\end{array}$ \\
\hline $\begin{array}{l}\text { R-Squared } \\
\text { Adjusted R-Squared }\end{array}$ & $\begin{array}{l}0.125 \\
0.106\end{array}$ & $\begin{array}{l}0.064 \\
0.045\end{array}$ & $\begin{array}{l}0.047 \\
0.027\end{array}$ & $\begin{array}{l}0.083 \\
0.064\end{array}$ \\
\hline
\end{tabular}

Note: $\quad{ }^{*} p<0.1 ; * * p<0.05 ; * * * p<0.01$ 